\title{
Exploration of offering photoelectric experimental general elective courses for college students of science and technology
}

\section{Shen Tao, Binchao Sun}

Shen Tao, Binchao Sun, "Exploration of offering photoelectric experimental general elective courses for college students of science and technology," Proc. SPIE 10452, 14th Conference on Education and Training in Optics and Photonics: ETOP 2017, 104523S (16 August 2017); doi: 10.1117/12.2264362

SPIE Event: 14th Conference on Education and Training in Optics and Photonics, ETOP 2017, 2017, Hangzhou, China 


\title{
Exploration of offering photoelectric experimental general elective courses for college students of science and technology
}

\author{
Shen Tao*, Sun Binchao \\ Department of Optical Informational Science and Technology, Harbin Univ. of Science and \\ Technology, West Campus, P.O. Box 130, Harbin, China 150080
}

\begin{abstract}
The necessity of offering photoelectric experiment general elective courses, such as the experiments of modern optical and innovational photoelectric design for non optic-electric's science and engineering students were discussed based on the analysis of the status quo and problems in experimental general elective course in science and engineering colleges of our country. And the characters of photoelectric disciplines, the goal of science and engineering quality-oriented education and the reform of science education at home and abroad were also considered. The instructional objectives, contents and characteristics of the courses were investigated. The specific methods, the CDIO (conceive, design, implement and operate) mode in the general courses has been proposed; the experiences and practical effects of offering these courses were concluded.
\end{abstract}

Keywords: Quality-oriented education, experimental courses, general elective courses, CDIO model, photoelectric design

\section{INTRODUCTION}

National medium-and Long-Term plain for Education Reform Development (2010-2020) pointed out wholly enforcement the undergraduate teaching quality and teaching reform project, efforts to promote quality education, promotion the communication with each subject, encourage students to participate in research, strengthen the practice teaching, improve the quality of personnel training. In order to strengthen the students' comprehensive ability, meeting the requirements for quality education, tendency of higher education developing, common basis elective general courses are subjected to the value more and more in the position and role of education in universities. However, it is limited by conditions, there is relative few experiment courses in this kind of elective courses. Wang Daheng, the father of China optics summarized the field of optic-electricity: Optics is both old and new, but the future is rosy. It can be seen, the optic-electric experiment has an irreplaceable role in training students' scientific inquiry ability. Science and technology education should combine with the actual social development, optic-electric specialized courses not only offer in the professional major, but also should be offered elective general courses in other majors, to popularize the optic-electric quality-oriented education. The optic-electric problems in daily life can be answered directly in the traditional type of optic-electric science and engineering courses, making the students whose majors are non optic-electric science and engineering can not answer the problems related to the optic-electric in daily life, not to mention to engage in simple practical optical design skills. This obviously can not adapt the requirement of high education to comprehensive cultivation of talents in science and engineering. In this case, offering elective general courses such as modern optical experiments, photoelectric design innovation experiments courses, etc for the non optic-electric students has great significance.

\section{DEFINITUDE TEACHING AIM}

Experimental general elective courses include cognitive general elective courses, design class general elective courses, racing general elective courses according to the nature of courses ${ }^{1}$. Traditional experimental teaching emphasizes the result too much, students just follow the teachers' instructions and the practice instructions to complete the experiment passively. The dominant method of teaching, the teachers usually ignore the students' scientific inquire, independent learning, independent analysis to solve the problems such as the cultivation of comprehensive ability, which contrary to the modern education of "teaching" to give a new meaning-"teaching students learning"2. For the non optic-electric science and engineering students learning the optic-electric elective general courses, needs to innovate the teaching

*taoshenchina@163.com; phone 13159854341

14th Conference on Education and Training in Optics and Photonics: ETOP 2017, edited by Xu Liu,

Xi-Cheng Zhang, Proc. of SPIE Vol. 10452, 104523S · ( 2017 ICO, IEEE, OSA, SPIE

CCC code: $0277-786 X / 17 / \$ 18 \cdot$ doi: $10.1117 / 12.2264362$

Proc. of SPIE Vol. 10452 104523S-1 
method according to professional characteristics and training.

Offering the photoelectric general elective courses is to achieve the goal of cultivating the students with a multidisciplinary way of thinking and a variety of methods to analyze the problems and develop the abilities, expand their horizons, learn more knowledge and improve the students scientific literacy. By learning photoelectric general elective courses, the students can further from the angle of scientific research and discuss question ability, widen the vision, inspire the mind, initiate the inspiration. At the same time, it can also make the students develop broad knowledge by learning the photoelectric general elective courses, post understanding, promote the intersection between the disciplines, broaden the students horizons. For the non optic-electric science and engineering students, offering the modern optical experiment, general elective courses, such as optic-electric design innovation experiment has both cognitive, design, racing function: First and foremost, through offering optic-electric general elective courses, the students can understand and cognitive the optic-electric theory and experiment. In addition, through introducing the CDIO mode into the teaching of the course, to make the students develop the ability of design and development of opticelectric products, get the ability of training in optical, mechanical and electrical, numerical integration system design. Last but not least, it is necessary to pay attention to cultivation of the students innovation ability in the curriculum, to provide the national students design competition of optic-electric training platform.

\section{HIGHLIGHTING CHARACTERISTICS OF COURSES}

Curriculum system is the important carrier which can realize the talents training target and mission, it determines the knowledge structure of the education subject, ability structure, and the overall quality, it is the core of the teaching plan $^{3}$. In the teaching process of science and engineering optic-electric, from the solid theoretical basis, offering courses such as college physics, optics, solid state physics, mathematical physics method, signal and system, hardware description language besides courses of circuit and electronic technique. On the basis of teaching reform, following the principle of "value foundation, broad knowledge, strengthening ability". Offering a system of optic-electric information science and engineering courses, taking advantage of strengthening the basic theory, developing the professional caliber, paying attention to practice teaching, choosing the professional direction well, and increasing the elective courses proportion. For offering the science optic-electric general elective experimental courses to lay the theoretical foundation. Hence, the optimized theory curriculum system should consists five parts: public basic course, the quality of administration in humanities and social science courses, the platform of basic courses, professional disciplines and professional direction courses. Detailed as follows:

Table 1. Theoretical teaching link.

\begin{tabular}{|c|c|c|}
\hline \multirow{2}{*}{$\begin{array}{l}\text { Basic } \\
\text { socializing } \\
\text { courses }\end{array}$} & Compulsory & $\begin{array}{l}\text { Advanced mathematics (science), Linear algebra, Probability and mathematical } \\
\text { statistics, Foreign language, C language programming, Sports, Physical } \\
\text { experiment }\end{array}$ \\
\hline & $\begin{array}{l}\text { Electives } \\
\text { (6score) }\end{array}$ & Elective for scope of whole school \\
\hline $\begin{array}{l}\text { Quality of } \\
\text { administrati } \\
\text { on in } \\
\text { humanities }\end{array}$ & Compulsory & $\begin{array}{l}\text { Thought morals tutelage and legal foundation, Principles of Marxism, Chinese } \\
\text { modern history outline, Generality of Maoism, Socialism with Chinese } \\
\text { characteristics, Management foundation of enterprise, Military theory, Education } \\
\text { of college students health, Employment guide of college students }\end{array}$ \\
\hline $\begin{array}{l}\text { and social } \\
\text { science } \\
\text { courses }\end{array}$ & $\begin{array}{l}\text { Electives } \\
(6 \text { score })\end{array}$ & Elective for scope of whole school \\
\hline $\begin{array}{l}\text { Discipline } \\
\text { basic }\end{array}$ & Compulsory & $\begin{array}{l}\text { Mechanical drawing, Circuit, Electronic technology, Thermodynamics and } \\
\text { statistical physics, Electromagnetics and electrodynamics, Atomic physics and } \\
\text { quantum mechanics, Method of mathematical physics, Solid state physics, } \\
\text { Modern physics experiment, Mechanics and theoretical mechanics, Optics, } \\
\text { Professional lectures }\end{array}$ \\
\hline & $\begin{array}{l}\text { Electives } \\
\text { (6score) }\end{array}$ & $\begin{array}{l}\text { Signal and system, Principles of communication, Semiconductor device, } \\
\text { Principles and applications of microcomputer, Digital integrated circuit design, } \\
\text { Microelectronics design }\end{array}$ \\
\hline $\begin{array}{l}\text { Professional } \\
\text { platform }\end{array}$ & Compulsory & $\begin{array}{l}\text { Laser principle and technology, Optical system design, Optic-electric detection } \\
\text { technology, optical fiber communication, Hardware description language }\end{array}$ \\
\hline
\end{tabular}




\begin{tabular}{|lll}
\hline courses & $\begin{array}{l}\text { Compulsory } \\
\text { orientation) } \\
\text { Compulsory } \\
\text { orientation) }\end{array}$ & $\begin{array}{l}\text { Optical fiber sensing technology, Optical testing technology, Optical components } \\
\text { and systems }\end{array}$ \\
$\begin{array}{l}\text { Information optics, Flat-panel display principle and application, Optic-electric } \\
\text { imaging principle and technology } \\
\text { Specialized } \\
\text { courses }\end{array}$ & $\begin{array}{l}\text { Professional foreign language, Principle and application of signal-chip } \\
\text { microcomputer, Spectroscope, Application of Matlab, Application of laser and } \\
\text { communications, Optical information processing and display experiment, } \\
\text { Lithograph process experiment, Optical fiber and optical passive components } \\
\text { technology, Integrated optics, Modern optical experiments }\end{array}$ \\
& &
\end{tabular}

In order to achieve the teaching goal, CDIO is introduced into the teaching of the course. CDIO is called "learning by doing", also known as project-based learning mode. The corresponding CDIO syllabus must be combined with the industry requirements, and the syllabus should be ongoing change. The students should carry out the syllabus of the industry of the major design, and carry out in accordance with the teaching mode based on CDIO engineering ability, it will eventually achieve the cultivation of the practical engineering application ability ${ }^{3-4}$.

\subsection{Introduction of CDIO}

In view of CDIO, the students cultivated should have four aspects: basic knowledge of engineering, personal ability, interpersonal ability of team and engineering system, it should be introduced CDIO before teaching courses, teaching courses, and after teaching courses to make the students achieve the goal at the four aspects.

\subsection{Introduction of CDIO before teaching courses}

The optic-electric general elective courses has a function of online teaching resources, it can also realize the function such as teaching resources, teaching video, network courseware, virtual experiment, online communication, interactive experiment, online examination ${ }^{5}$. Students utilize the network teaching resources before having courses, realizing the cultivation of students ability of CDIO in engineering foundation, and based on the students' own thinking and the activity of solving problems, it can achieve the goal of self-learning in CDIO.

\subsection{Introduction of CDIO when teaching courses}

\section{(1) Realization of integrative teaching project}

During the courses of curriculum and teaching, realizing the innovation mode of learning theory in the process of experiment, teaching theory guides the experiment. Realizing the effective development of students' abilities of engineering foundation, personal ability, and the abilities of engineering system in CDIO. Fusing basic personal ability, interpersonal ability and the cultivation of the ability to build products, process and system to achieve the rule of CDIO teaching project.

\section{(2) Realization of learning goals and comprehensive learning experience}

In the experiment teaching, students on the basis of completing the corresponding demonstration validation experiments, operating the comprehensive experiments, and then carry on the design of experimental design, and on the basis of the above cooperation with classmates on a creative experiment ${ }^{6}$. Through the series of process and specific learning realizes the students' personal abilities and interpersonal ability of team training effectively in CDIO, to achieve the principles of learning goal and comprehensive learning experience of CDIO.

(3) Realization of students' assessment

Examination mode will be reformed for the courses, Establishing the scientific reasonable and student-oriented, covering the network preview, experimental operation, the final examination and defense way of curriculum assessment. The examination result contains: the final written examination, the ordinary time examination, experiment report, defense, etc. Each of them is at a certain percentage. The final written examination is focused on optic-electric design related the principles, equipment, and the experiment. It is paid attention to the process of experimental operation and the design capabilities in the ordinary time examination. The experiment report pays attention to the student' abilities to grasp and understand the experiment, and the defense pays attention to the courses of optic-electric design innovation of the 
students' abilities ascension ${ }^{7}$. At the same time, the students in their final examination, experiment report and the lowest score of the three links at ordinary times, the students must attend the question-and-answer session for good grades ${ }^{8}$. Through the scientific evaluation to the students' abilities of the basic personal and interpersonal skills, products, process and systems to build capability and subject knowledge to CDIO standards of students' evaluation into the assessment.

\subsection{Introduction of CDIO after teaching courses}

(1) Realization of design and implementation experience

For the students whose grades are excellent and the innovation abilities are outstanding, these students will be accepted the follow-up training project. They will be trained in the laboratory of optic-electric science and innovation laboratory or optic-electric engineering practice laboratory for one year. During the process of training, it will be provided a resources such as training platform for the students through college students' innovation entrepreneurial training plan, college students' innovation experiment, and the relevant course design and the graduation design project team, teachers' research projects. The students who attend the follow-up training should obtain an authorized patent or publish a related paper at least, and should be recommended to participate the national students college optic-electric design competition. To achieve the design and implementation experience in the CDIO criterion in this way.

(2) Realization of engineering practice place

On the basis of curriculum, establishing a optic-electric science and technology innovation laboratory, optic-electric engineering practice laboratory, etc, perfecting the function of laboratory, it provides the conditions for various experiment competitions, college students' innovation entrepreneurial training program, course design and graduation design, etc, and provide national students design competition of the optic-electric platform ${ }^{9}$. It conforms to the rule of CDIO engineering practice in the workplace.

(3) Realization of improvement of teachers' abilities and teachers' teaching abilities

Realization of utilization of lab instrument, apparatus and resource sharing, it has a practical significance for experimental reforming technology related personal and teachers guide the students in school to participate the national college students design competition of optic-electric. It also has realistic meaning to implement for the teachers' abilities and the teachers' teaching abilities in the CDIO criterion.

\section{SELECTION OF EXPERIMENT CONTAINS}

It is determined the courses include two parts of teaching contains according the teaching purpose, combining the characteristics of courses, considering the schedules. The two parts are: the first is to introduce the basic theory of optics and optic-electric information and optic-electric devices, devices and basic experiment technology, with improving the students' abilities to optics and optic-electric information theory and design, at the same time, providing the basis for the national college students optic-electric design competition. The second is to apply five great dozens of experimental projects such as optics generation, transmission, display, processing and design. Paying attention to develop the students' abilities of independent design ability and innovation thinking. The excellent students are recommended to participate the national college students optic-electric design competition further ${ }^{10}$.

It will be introduced the common used instruments and devices, the basic experimental technology, light generation, light transmission, display, processing and optic-electric design theory in the theory courses. It will be done natural light, polarized light, laser and characteristic of visible light experiment in the experimental courses of light generation.It will be done optical communication, laser optical transmission, optical fiber communication, spatial light, and special transmission mode of light experiment in the experimental courses of light transmission. It will be down CCD display, optical flat-panel display, spatial light display, and special display of light experiment in the experimental courses of light display. It will be down electric-optic and acousto-optic modulation, optical holography processing, liquid crystal light value processing, and AFM micro-nano processing experiment in the experimental courses of optical processing. It will be down light generation, transmission, display, processing, design of optic-electric integrated innovation experiment in the experiment courses of optical design. At the same time, on the completion of demonstration and verification, on the basis of comprehensive, designing experiment, the students complete an optic-electric design innovation experiment in teamwork, and use the result to reply in support. 


\section{REFORM THE METHOD OF INSPECTION}

At present, the appraisal method of most of the experimental courses is to submitted a report as the main basis. If the lab report is finished well, the result is excellent or good, on the other hand, the result is qualified or unqualified. It will ignore the students' performance in class and after class, especially ignore the students' innovation thinking ${ }^{11}$. The students' achievement can't fully reflect the students grasp of the basic operation skills and proficiency, and whether has the preliminary design of experiment ability, analysis ability to the success or failure of the experiment, etc. To some extent, this is unfair and unreasonable, and damps down some of the students' learning initiative and enthusiasm, it is harmful for quality education. To make the experimental courses play a more important role in quality education, in the reform of teaching methods, teaching mode should be also reformed at the same time, and the assessment of experimental courses should also be reformed to a certain extent, for the cultivation of high-quality talents.

For fair, just, reasonable and innovation of experimental assessment, it is necessary to take the oral examination, written examination, operation, reply support method to assess the students in addition to the manifestation to the students and their experimental report submitted for review. It is determined of the appraisal method according to the appraisal content, experimental conditions and the students' specific circumstances ${ }^{12}$. To make assessment of the courses reflects on the students' self-study ability, hands-on ability, observation ability, analytical ability, the unity cooperation ability, written expression ability, independent innovation ability and the comprehensive evaluation of scientific experiment quality.

\section{EVIDENCE OF PRACTICAL EFFECT}

In the recent two years, six sessions of training program were set up through optic-electric experimental courses for cultivating students national college students' innovative entrepreneurial project. The students get various awards related to the optic-electric courses such as the challenge cup, electronic design competition, the physical demonstration instrument design competition, Freescale intelligence car competition. The teachers complete five provincial teaching reform project in the process of curriculum reform, won two teaching achievement prizes at the provincial level, and it has accumulated profound basis in exploring the suitable education teaching method. Through learning these courses the students were build a good foundation for the post graduate entrance examination or looking for jobs. The students related qualities grow significantly in recent years. Most of the graduated students think that it has played a more obvious role of the students' theory learning, experimental skills training, innovation ability training, design of the application system and the improvement of production capacity based on the teaching reform of the project.

\section{CONCLUSION}

Optic-electric experimental courses are the theory and practice, the medium of basic applied courses for the majoring students. As the general elective course, it plays a role of knowledge spread, thinking method and learning method training for the non optic-electric science and engineering students, and it implements the success they learned in class to practice and influence their future of study and life. It realized the practical, continuation and development of knowledge besides teaching knowledge.

\section{ACKNOWLEDGEMENT}

Heilongjiang province education scientific planning priority subject in 2015: Cooperative education mode optic-electric information professional study and practice of new academic tutorial system (GJB1215035); Special education teaching research project of Harbin University of Science and Technology: "Network+" optic-electric innovation practice curriculum construction (120150005).

\section{REFERENCES}

[1] Yang, X. D., Yang, H., Ni X., Sun, J. D., and Gao, H. T., "Construction and application of the information management system for experimental elective courses." China Modern Educational Equipment. Papers 11, 2325 (2012). 
[2] Yan, X. H., Wang, N., and Teng X. H., "Reform and Practice of Experimental Teaching of BioinformaticsApplication of Problem-based Learning to Bioinformatics. " Journal of Northeast Agricultural University(Social Science Edition). Papers 7(5): 99-101 (2007).

[3] Ye, W. W., and Kong, H. B., "A case study of CDIO-based industry-university cooperation education of engineering." Research in Higher Education of Engineering. Papers S2: 34-39 (2008).

[4] Wang, S. W., and Hong, C. W., "CDIO: the classic mode of engineering education in MIT-an unscrambling on the CDIO syllabus." Journal of Higher Education in Science \& Technology. Papers 28(4): 116-119 (2009).

[5] Wang, W. J., Zhang, X. Y., and Li, N., "Reform of exam models of experimental course from reforming curriculum system." Journal of Baicheng Normal College. Papers 21(3): 71-73 (2007).

[6] Pang, H. S., and Huan, X. H., "Reformation of university education caused by Suzhi education." China higher education research. Papers 9: 73-77 (2015).

[7] Lu, L. J., "Approaches to the innovation multi-dimensional experiment teaching and practice." Physical experiment of college. Papers 27(3): 129-132 (2014).

[8] Zhang, T., Wu, Q., Guo, Y. J., and Jiang, Z. R., "The construction of education curriculum for the university student innovation training." Research and exploration in laboratory. Papers 32(11): 490-492 (2013).

[9] Dong, L. B., "An analysis of curriculum reform in universities and colleges based on 'students-centered'." Higher education of science. Papers 1: 103-107 (2013).

[10] Cheng, Y., Li, S. K., and Jiang, C. F., "Exploration on construction of engineering general course." Research in higher education of engineering. Papers 3:177-180 (2013).

[11] Jiang, W. J., Xie, W., Shi, J. H., and Mao Haotong. "The study and practice integrate design curriculum's teaching." Journal of higher education research, Papers 37(2): 105-109 (2014).

[12]Zhao, X. Y., "Exploration and practice of teaching specialized courses for photoelectric information majors." China science and technology information. Papers 3: 246-248 (2010). 